\title{
Evaluation of the Neuroprotective Effects of Centella asiatica Against Scopolamine Induced Cognitive Impairment in Mice
}

\author{
Sunanda BPV ${ }^{1}$, Latha $\mathrm{K}^{1}$, Rammohan B' ${ }^{1}$, Uma Maheswari MS ${ }^{1}$ and Surapaneni Krishna Mohan ${ }^{2 *}$ \\ 1'Department of Pharmacology, Karpagam Faculty of Medical Sciences and Research, Coimbatore - 641 032, Tamilnadu, India \\ ${ }^{2}$ Department of Biochemistry, Saveetha Medical College \& Hospital, Faculty of Medicine, Saveetha University, Saveetha Nagar, \\ Thandalam, Chennai - 602 105, Tamilnadu, India
}

\begin{abstract}
Objective: This study was conducted to show Neuroprotective effect of aqueous extract of Centella asiatica in scopolamine induced cognitive impairment in mice. The improvement of cognitive impairment with Centella asiatica was compared against standard drug (Donepezil $50 \mu \mathrm{g} / \mathrm{kg}$ ). Methods: Swiss albino mice $(20-25 \mathrm{~g}$ ) of either sex were randomly divided into 5 groups of 6 animals each. All the animals except the control group, received scopolamine $(0.05 \mathrm{mg} / \mathrm{kg})$ for 14 days. In day of 14 th each animal was checked for cognitive impairment by using elevated plus maze (EPM). Dried powder of Centella asiatica (CA) was boiled with distilled water, cooled, filtered, placed on hotplate for complete evaporation, finally weighed and stored. The control group (Group 1), scopolamine control (Group 2) test groups (CA-150 mg/kg as Group 3 \& 300 $\mathrm{mg} / \mathrm{kg}$ as Group 4) and standard drug (Group 5) received normal saline, Scopolamine, Centella asiatica (CA) extract (150 \& $300 \mathrm{mg} / \mathrm{kg}+$ Scopolamine), donepezil $(50 \mu \mathrm{g} / \mathrm{kg})$ respectively by oral feeding. The Neuroprotective effect was assessed by elevated plus maze (EPM). Institutional Ethical Committee approval was obtained before the start of the study. Results: In elevated plus maze (EPM) models, it implies that Centella asiatica (CA) $300 \mathrm{mg} / \mathrm{kg}$ (group IV) significantly $(\mathrm{p}<0.001)$ decreases the retention transfer latency. Conclusion: The current study demonstrates statistically significant Neuroprotective activity of Centella asiatica (CA).
\end{abstract}

Keywords: Centella asiatica (CA), neuroprotection, scopolamine, donepezil, Elevated plus Maze (EPM), cognitive impairment

\section{INTRODUCTION}

Dementia is defined as a loss of intellectual abilities that is severe enough to interfere with social or occupational functioning. Cognitive impairment is a progressive neurodegenerative disorder and causes significant dementia in elderly. Alzheimer's disease (AD) is the most common cause of dementia, comprising $50-70 \%$ of all cases. ${ }^{1} \mathrm{AD}$ is characterized by early memory deficits, followed by the gradual erosion of other cognitive functions. The most severe Neu- ropathological changes occur in the hippocampus, followed by the association cortices and Subcortical structures, including the amygdala and Nucleus Basalis of Meynert. ${ }^{2}$ The $\mathrm{AD}$ brain is characterized by massive neuronal cell and synapse loss at specific sites, as well as $\beta$-amyloid plaques and Neurofibrillary lesions.

The major protein component of plaques is the polypeptide $A \beta$ that is derived from Amyloid Precursor Protein (APP). The Neurofibrillary lesions contain hyper phos-
Submission Date : 20-02-14 Revision Date : 16-06-14 Accepted Date : 03-09-14

DOI: 10.5530/ijper.48.4.5

Address for correspondence: Dr. Surapaneni Krishna Mohan

Associate Professor, Department of Biochemistry, Saveetha Medical College \& Hospital, Faculty of Medicine, Saveetha University, Saveetha Nagar, Thandalam, Chennai - 602 105, Tamilnadu, India.

E-mail: krishnamohan. surapaneni@gmail.com

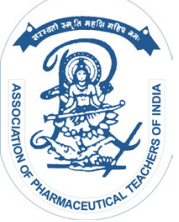

www.ijper.org 
phorylated aggregates of the microtubule-associated protein Tau and are found in cell bodies and apical dendrites as Neurofibrillary Tangles (NFTs), in distal dendrites as neutrophil threads, and in the abnormal neuritis that are associated with some $\beta$-amyloid plaques. ${ }^{3-6}$

Majority of animal models to induce AD are based on the cholinergic hypothesis of AD. Degeneration of cholinergic neurons in the Nucleus basalis of Meynert, situated in the basal forebrain and primarily projecting to the Neocortex, occurs early in the course of the disease. ${ }^{7}$ A correlation between cholinergic deficits and both cognitive symptomatology and the extent of Neuropathological alterations in AD was reported. ${ }^{8,9}$

The most commonly used pharmacological model related to cognitive impairment or $\mathrm{AD}$ is scopolamineinduced amnesia. ${ }^{10,11}$ which has increased our knowledge of the role of the cholinergic system in cognition and allows preclinical evaluation of symptomatic efficacy of cholinomimetics, including mainly compounds with presumed Acetylcholinesterase inhibiting activity ${ }^{12}$ and muscarinic receptor 1 agonists. ${ }^{13}$

Scopolamine, a microtubule disrupting agent causes cytoskeletal alterations and axonal transport dysfunction ${ }^{14}$ leading to death of cerebellar granule cells, olfactory bulb neurons, cells of sub ventricular zone, dentate gyrus cells, and basal forebrain cholinergic neurons, ${ }^{15}$ thus causing cognitive impairment. Central administration of scopolamine causes excessive free radical generation and oxidative damage that can be positively correlated with the extent of cognitive impairment. ${ }^{16}$ Scopolamine administration is characterized by progressive deterioration of learning and memory, oxidative stress, and decrease in acetylcholine turnover. ${ }^{17,18}$

\section{MATERIALS AND METHODS}

Preparation of Aqueous Extract: Leaves of Centella asiatica (CA) were collected from local garden in Coimbatore, dried in shadow, and subsequently grounded. The plant was authenticated for their correct botanical identity by the chief botanist. Powdered samples (250 g) were refluxed with 1.5 liters of distilled water at ratio 1:6 for 3 hours at temperature approximately $40^{\circ} \mathrm{C}$. The extracts were left to cool at room temperature before it was filtered. ${ }^{17}$ By filtering we removed the debris of plants and then it was freeze-dried to yield a residue. The mixture was subsequently concentrated at $35^{\circ} \mathrm{c}$ in hotplate. The extract was preserved in deep freeze in air tight container.

Animals: Swiss albino mice $(20-25 \mathrm{~g})$ of either sex were procured from the central animal house of the Institute. They were housed in standard polypropylene cages and were kept under controlled room temperature at $25 \pm 20 \mathrm{C}$ in a $12 \mathrm{~h}$ light / dark cycle. Animals were fed dry pellets and water ad libitum. The animals were accustomed during the day time to new environment for at least 3 days prior to the experiment. Institutional Animal Ethics Committee approval was taken before the study has started (KFMSR/IAEC/2013/004; dated 04.10.2013). The ethical guidelines of CPCSEA for the investigation on animals followed in all the tests.

Elevated Plus Maze (EPM): Mice were divided into 5 groups. Each group was consisting of 6 mice. The elevated plus maze consisted of two opposite black open arms $(50 \times 10 \mathrm{~cm})$, crossed with two closed arms of the same dimensions with $40 \mathrm{~cm}$ height walls. The arms were connected with a central square of dimensions 10 $\mathrm{cm}$. The entire maze was elevated to a height of $50 \mathrm{~cm}$ from the floor.

Memory was tested on day one in the elevated plus maze. Animal was placed individually at one end of the open arm facing away from the central square. The time taken by the animal to move from the open arm to the closed arm was recorded - it was considered as the initial transfer latency (ITL). Animal was allowed to explore the maze for 20 seconds after recording the ITL and then returned to the home cage.

If the animal did not enter the enclosed arm within 90 seconds, it was guided on the back into one of the enclosed arm and the ITL was given as 90 seconds. Retention of memory was assessed by placing the rat in an open arm on day 14 and day 21 and it was termed as the first retention transfer latency $\left(1^{\text {st }}\right.$ RTL) and second retention transfer latency $\left(2^{\text {nd }} \mathrm{RTL}\right)$, respectively. ${ }^{19,20}$

\section{STATISTICAL ANALYSIS}

Data were expressed by Mean \pm SEM. For comparison among the groups we used ANOVA with multiple comparisons by Posthoc Dunnett t-test method. Statistical analysis done by using SPSS for windows (V: 17.0). Statistical significance was considered $\mathrm{p}<0.05$ level.

\section{RESULTS}

\section{Elevated Plus Maze (EPM)}

The mean duration of initial transfer latency, $1^{\text {st }}$ retention transfer latency and $2^{\text {nd }}$ retention transfer latency for all the groups were recorded. The duration was decreased with CA $300 \mathrm{mg} / \mathrm{kg}$ significantly $(\mathrm{p}<0.001)$. But on comparison to the standard drug donepezil, it was low. It implies that CA $300 \mathrm{mg} / \mathrm{kg}$ significantly $(\mathrm{p}<0.001)$ decreases the duration of $1^{\text {st }}$ and $2^{\text {nd }}$ retention transfer latency in scopolamine induced cognitive impaired mice. The percentage decrease in duration was 
compared with control and it was found to be statistically significant $(\mathrm{p}<0.001)$.

Shown in the (Table 1 \& Figure 1). CA having dose dependent improvement in cognitive impairment on EPM.

\section{DISCUSSION}

This study was aimed to evaluate the Neuroprotective properties of CA in comparison with standard drug using animal models. CA is a perennial stem less herb, indigenous ingredients of ayurvedic medicine. It is mainly used for its memory enhancing property, anti-inflammatory, immunomodulating, anti-prolif- erative, antitumor, antibacterial, and Antioxidant ${ }^{21}$ properties. In the present study CA was used in a dose of 150 and $300 \mathrm{mg} / \mathrm{kg}$ as cognition enhancer. In these doses CA decreases the duration of $1^{\text {st }}$ and $2^{\text {nd }}$ retention transfer latency as compared to control in a dose dependent manner. But CA $300 \mathrm{mg} / \mathrm{kg}$ was showed a significant $(\mathrm{p}<0.001)$ reduction in $1^{\text {st }}$ RTL \& $2^{\text {nd }}$ RTL.

Scopolamine induced cognitive impairment in mice and elevated plus maze is a best suitable test for evaluating Neuroprotective properties of drugs, because it is the best-validated preclinical test that predicts drugs effective against cognitive impairment in mice. Scopolamine

\begin{tabular}{|c|c|c|c|c|}
\hline SI. No & $\begin{array}{c}\text { Group \& Dose } \\
\text { (mg/kg oral ) } \\
n=6\end{array}$ & $\begin{array}{c}\text { Initial transfer } \\
\text { latency in seconds } \\
\left(1^{\text {st }} \text { day }\right) \\
\text { Mean } \pm \text { SEM }\end{array}$ & $\begin{array}{l}1^{\text {st }} \text { retention transfer } \\
\text { latency in seconds } \\
\left(14^{\text {th }} \text { day }\right) \\
\text { Mean } \pm \text { SEM }\end{array}$ & $\begin{array}{c}2^{\text {nd }} \text { retention transfer } \\
\text { in seconds } \\
\left(21^{\text {st }} \text { day }\right) \\
\text { Mean } \pm \text { SEM }\end{array}$ \\
\hline 1 & $\begin{array}{l}\text { Control } \\
\text { (Normal saline; } 0.5 \mathrm{ml} \text { ) }\end{array}$ & $52.17 \pm 0.48$ & $50.83 \pm 0.31$ & $50.17 \pm 0.60$ \\
\hline 2 & Scopolamine Control $(0.05 \mathrm{mg} / \mathrm{kg})$ & $51.17 \pm 0.31$ & $78.50 \pm 1.46^{\star \star *}$ & $86.83 \pm 0.75^{\star * *}$ \\
\hline 3 & $\begin{array}{l}\text { Centella asiatica }(150 \mathrm{mg} / \mathrm{kg})+ \\
\text { Scopolamine }\end{array}$ & $50.17 \pm 0.54^{*}$ & $43.17 \pm 0.65^{\star * *}$ & $38.50 \pm 0.50^{\star \star *}$ \\
\hline 4 & $\begin{array}{l}\text { Centella asiatica }(300 \mathrm{mg} / \mathrm{kg})+ \\
\text { Scopolamine }\end{array}$ & $50.50 \pm 0.67$ & $37.50 \pm 0.43^{* * *}$ & $33.17 \pm 0.79^{* * *}$ \\
\hline 5 & Donepezil $(50$ g/kg) & $51.0 \pm 0.58$ & $33.33 \pm 0.62^{* \star *}$ & $30.33 \pm 0.42^{* * *}$ \\
\hline
\end{tabular}

${ }^{*} \mathrm{P}<0.05$ Compared to Controls; ${ }^{* * *} \mathrm{P}<0.001$ Compared to Controls

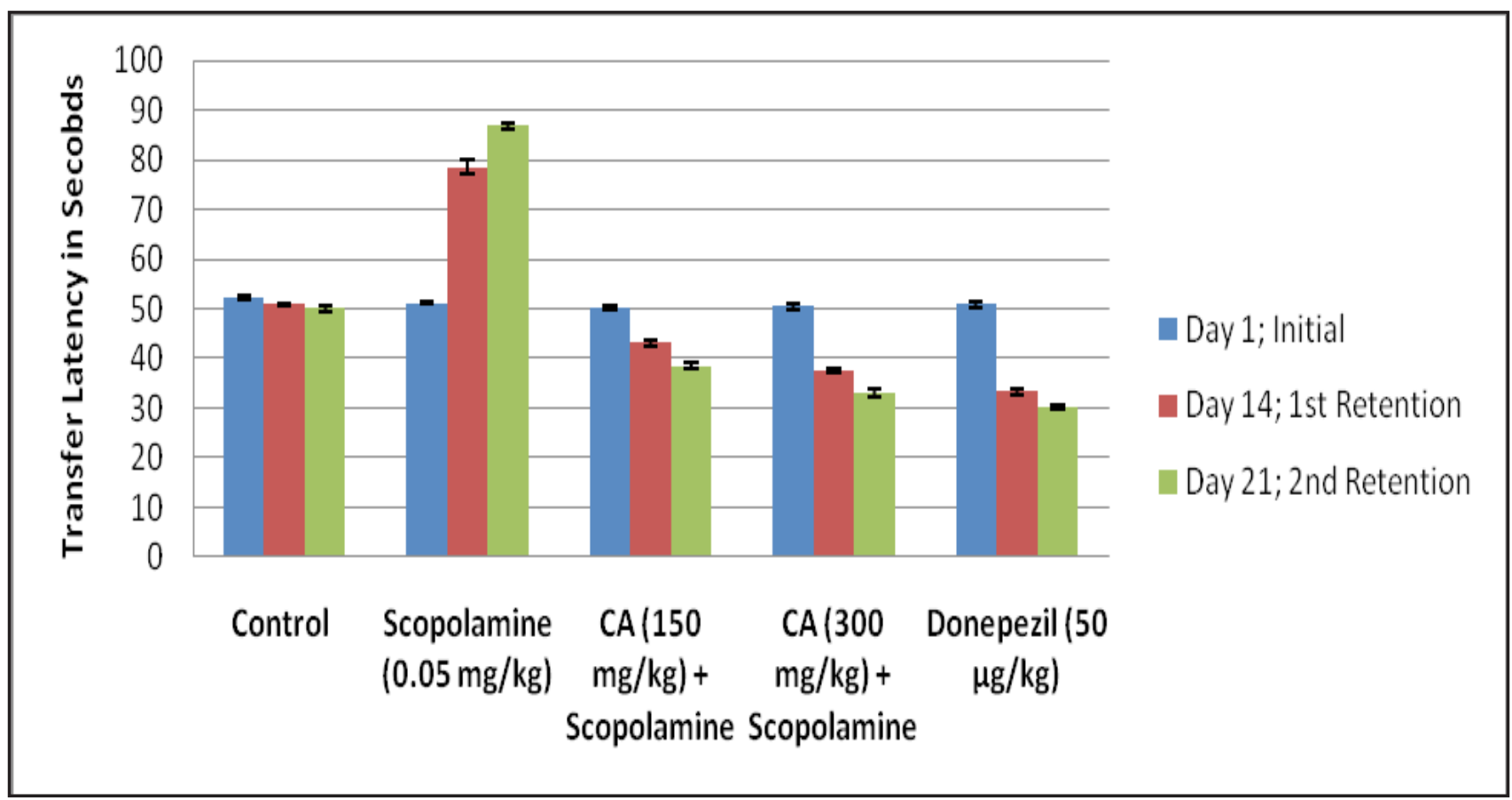

Figure 1: It shows the effect of Centella asiatica (CA) on Elevated plus Maze [EPM] in Cognitive Impaired Mice. 
administration is characterized by progressive deterioration of learning and memory, oxidative stress, and decrease in acetylcholine turnover. ${ }^{17,18}$

CA leaf extract has been reported to improve spatial learning performance and enhance memory retention in neonatal rats during growth spurt period and also found efficient in enhancing hippocampal CA3 neuronal dendritic arborization in mice. ${ }^{22,23}$ In our study, CA showed Neuroprotective activity with 150 and $300 \mathrm{mg} / \mathrm{kg}$ but it was significant in $300 \mathrm{mg} / \mathrm{kg}$ group when compared to control group. It has low activity when compared to that of standard drug donepezil.

In this study, when scopolamine is given, showed memory impairment in elevated plus maze tasks which were attenuated by $\mathrm{CA}$ treatment. So, the chronic administration of CA was able to improve the cognitive deficit and attenuated oxidative stress, suggesting that $\mathrm{CA}$ improves cognitive task. ${ }^{24-27}$

\section{CONCLUSION}

Hence, the present study suggests that long term administration of CA prevents scopolamine-induced cognitive impairment and associated oxidative stress. Thus, the use of CA is promising for the treatment of Alzheimer's diseases (AD) and other neurodegenerative disorders.

\section{CONFLICT OF INTERESTS}

None

\section{ACKNOWLEDGEMENTS}

The Authors are very much thankful to Dr. S. Porchelvan, M.Sc., M.B.A., PGDCA., PhD., Professor in Biostatistics, Saveetha Medical College \& Hospital, Saveetha University for assisting us in performing the statistical analyses.

\section{REFERENCES}

1. Ballatore C, Lee VM, Trojanowski JQ. Tau mediated neurodegeneration in Alzheimer's disease and related disorders. Nature Rev. Neurosci. 2007; 8(9): 663-72.

2. Arnold SE, Hyman BT, Flory J, Damasio AR, Van Hoesen GW. The topographical and neuroanatomical distribution of neurofibrillary tangles and neuritic plaques in the cerebral cortex of patients with Alzheimer's disease. Cereb. Cortex. 1991; 1(1): 103-16.

3. Selkoe DJ. Alzheimer's disease is a synaptic failure. Science. 2002; 298(5594): 789-91.

4. Lee VM, Goedert M, Trojanowski JQ. Neurodegenerative tauopathies. Annu. Rev. Neurosci. 2001; 24(1): 1121-59.

5. Kiyofumi Yamada, Toshitaka Nabeshima. Animal models of Alzheimer's disease and evaluation of anti-dementia drugs. Pharmacology \& Therapeutics. November 2000; 88(2): 93-113.
6. Michael P, Mcdonald, Bruce overmier J. Present Imperfect: A Critical Review of Animal Models of the Mnemonic Impairments in Alzheimer's Disease. Neuroscience \& Biobehavioral Reviews. 1997; 22(1): 99-120.

7. Davies P, Maloney AJ. Selective loss of central cholinergic neurons in Alzheimer's disease. Lancet. 1976; 308(8000): 1403.

8. Martin EM, Wilson RS, Penn RD, Fox JH, Clasen RA, Savoy SM. Cortical biopsy results in Alzheimer's disease: correlation with cognitive deficits. Neurology. 1987; 37(7): 1201-4.

9. Bierer LM, Haroutunian V, Gabriel S, Knott PJ, Carlin LS, Purohit DP, et al. Neurochemical correlates of dementia severity in Alzheimer's disease: relative importance of the cholinergic deficits. J Neurochem. 1995; 64(2): 749-60.

10. Sunderland T, Tariot PN, Weingartner H, Murphy DL, Newhouse PA, Mueller EA, et al. Pharmacologic modelling of Alzheimer's disease. Prog Neuro psychopharmacol Biol Psychiatry. 1986; 109(3): 599-610.

11. Ebert U, Kirch W. Scopolamine models of dementia: electroencephalogram findings and cognitive performance. Eur J Clin Invest. 1998; 28: 944-9.

12. Trabace L, Cassano T, Steardo L, Pietra C, Villetti G, Kendrick $\mathrm{KM}$, et al. Biochemical and neurobehavioral profile of CHF2819, a novel, orally active acetylcholinesterase inhibitor for Alzheimer's disease. J Pharmacol Exp Ther. 2000; 294(1): 187-94.

13. Malviya M, Kumar YC, Asha D, Chandra JN, Subhash MN, Rangappa KS. Muscarinic receptor 1 agonist activity of novel $\mathrm{N}$-arylthioureas substituted 3-morpholino arecoline derivatives in Alzheimer's presenile dementia models. Bioorg Med Chem. 2008; 16(15): 7095-101.

14. Müller J, Geist MA, Veng LM, et al. A role for mixed lineage kinases in granule cell apoptosis induced by cytoskeletal disruption. Journal of Neurochemistry. 2006; 96(5): 1242-52.

15. Goldschmidt B, Steward O. Neurotoxic effects of scopolamine: differential susceptibility of CNS neuronal populations. Neuroscience. 1982; 7(3): 695714.

16. Kumar HV, Gupta YK. Intra cerebro-ventricular administration of scopolamine produces cognitive impairment associated with oxidative stress in rats. Pharmacology Biochemistry and Behavior. 2002; 73(3): 565-71.

17. Bensimon $G$, Chermat R. Microtubule disruption and cognitive defects: effect of scopolamine on learning behavior in rats. Pharmacology Biochemistry and Behavior. 1991; 38(1): 141-5.

18. Yuzo Nakagawa, Shizuo Nakamura, Yoshitoshi Kaśe, Teruhisa Noguchi, Takafumi Ishihara. Colchicine lesions in the rat hippocampus mimic the alterations of several markers in Alzheimer's disease. Brain Research. 1987; 408(1-2): 57-64.

19. Gupta SK. Drug Screening Methods - Preclinical Evaluation of New Drugs. Drugs screening methods. 2009; 2: 234-8. DOI: 10.5005/jp/books/10244

20. Ghosh MN. Fundamentals of experimental pharmacology. Indian J Pharmacol. 2007; 39(4): 216

21. Mutua PM, Gicheru MM, Makanya AN, Kiama SG. Anti-Proliferative Activities of Centella asiatica Extracts on Human Respiratory Epithelial Cells in vitro. Int. J. Morphol. 2013; 31(4): 1322-7.

22. Rao GM, Rao SM, Rao SG. Centella asiatica (linn) induced behavioural changes during growth spurt period in neonatal rats. Neuroanatomy. 2005; 4: 18-23.

23. Rao KGM, Rao SM, Rao SG. Enhancement of Amygdaloid Neuronal Dendritic Arborization by Fresh Leaf Juice of Centella asiatica (Linn) During Growth Spurt Period in Rats. Evidence-Based Complementary and Alternative Medicine. 2007; 6(2): 203-10.

24. Nadkarni KM, Nadkarni AK. Indian material medica III edition. Bombay, Popular Prakashan. 2005; 663-4.

25. Soumyanath A, Zhong YP, Gold SA, Yu X, Koop DR, Bourdette D, Gold BG Centella asiatica accelerates nerve regeneration upon oral administration and contains multiple active fractions increasing neurite elongation in vitro. $\mathrm{J}$ Pharm Pharmacol. 2005; 57(9): 1221-9.

26. Rao SB, Chetana M, Uma Devi P. Centella asiatica treatment during postnatal period enhances learning and memory in mice. Physiology and Behavior. 2005; 86(4): 449-57.

27. Kumar MHV, Gupta YK. Effect of different extracts of Centella asiatica on cognition and markers of oxidative stress in rats. Journal of Ethnopharmacology. 2002; 79(2): 253-60. 